\title{
National signs: Estonian identity in performance
}

\author{
Janelle Reinelt \\ Department of Drama, University of California \\ Irvine, CA 92697-2775, USA \\ e-mail: jreinelt@rgs.uci.edu
}

\begin{abstract}
Since Estonia is in the midst of a national redefinition and examination of past traditions and future aspirations, it makes an excellent case study for the potentiality of theatre as an arbiter of national identity. The changing value of the institution itself is part of the equation (will Estonians continue to appreciate and attend the theatre in coming years?). In addition, the historical role of Estonian theatre as a repository for national narratives, especially literary ones, makes it a significant site for struggles around print and technology, and between embodied performances and archival performatives.

This essay introduces a series of articles that address how Estonia and its theatre might be regarded and understood in light of its history, memories, present experiences, and future possibilities. The idea of pretence that lies at the heart of theatricality itself provides an ideal means for interrogating national identity in a time of great instability and flux. The examples of productions discussed in these three essays share more than a deliberate utilization of the rubrics of theatricality. It seems no coincidence that the reworking of national classics, Estonian national myths, and ethnic folk songs and ceremonies takes place concurrently with the representation of new technologies, commodity capitalism, and diasporic collisions. Embodying precisely the predicament of culture in a country reassessing its past and confronting its future, the theatre is an important institution for national resignification.
\end{abstract}

For several decades now, scholars in many fields have examined and theorized national identities and the relationship between their formations and modifications. Joining social scientists and humanists, theatre and performance scholars have also participated in this project, dating most clearly from Loren Kruger's The National Stage: Theatre 
and Cultural Legitimation in England, France, and America (1992). ${ }^{1}$ As the century turned, questions concerning the limitation of the very concept of "nation states" in light of the rapidly changing global world became more frequent and insistent, and a need to reassess the role of national identity in contemporary culture began to assert itself. From one perspective, the creeping globalization of media and technology seems to have saturated the national imaginations of many countries, where children may be more familiar with Disney characters than their own nation's folklore or children's literature. On the other hand, local traditions, practices, and cultures continue to persist and provide deep structures of meaning and identification for many. No where is this problematic dualism more apparent than in the former Soviet-bloc countries, the Eastern European nations, that since 1989 have been redefining their self-understandings.

Precisely because Estonia is in the midst of such a redefinition and examination of past traditions and future aspirations, it makes an excellent case study of the efficacy of theatre as an arbiter of national identity. The changing value of the institution itself is part of the equation (will Estonians continue to appreciate and attend the theatre in coming years?). In addition, the historical role of Estonian theatre as a repository for national narratives, especially literary ones, makes it a significant site for struggles around print and technology, and between embodied performances and archival performatives. ${ }^{2}$

At a recent conference, "National Theatres of Europe: Constructing National Identities", the Irish journalist Fintan O'Toole remarked, "National theatres pretend that a nation exists, at least for the duration of the theatre piece". ${ }^{3}$ Whether the theatre in question is a monumental building carrying official status as National and supported by state subsidy, or whether it is a small, independent company performing in a warehouse, both theatres can pretend that a nation exists - this pretense consists of the address to the audiences assembled and its absent but imagined compatriots, and it can take the form of any subjunctive stage reality. The assembly of actual material

For other recent scholarship on this topic, see for example Kobialka (1999), and Mäkinen et al. (2001); my own related work can be found in these volumes and in Colleran, Spencer (1998).

2 See Diana Taylor's discussion in The Archive and the Repertoire: Performing Cultural Memory in the Americas (2003).

3 Organized by Stephen Wilmer at Trinity College Dublin, March 11-13, 2005. 
bodies in the theatre may itself invoke a nation more strongly than either print or media cultures.

In the case of Estonia, the question is, of course, not whether a nation now exists, but how it is to be regarded and understood in light of its history, memories, present experiences, and future possibilities. Nevertheless, this idea of pretence is at the heart of theatricality itself, and provides an ideal means for interrogating national identity in a time of great instability and flux. As Luule Epner writes in her contribution, "The action defined as play in a ludic space of theatre makes it possible to easily deconstruct and reconstruct fictional worlds." All the essays collected here mention the high levels of reflexivity and meta-theatrical strategies present in the recent Estonian theatre performances these scholars discuss. The theatrical apparatus itself at once puts in play a kind of promiscuous and variable set of diverse signifiers, and offers the stage as a contrastingly material and even stable space for public experience and consideration of shared identities.

This reaffirmation of a public sphere is perhaps more potent in small countries where gathering together groups of citizens to consider their own shared polity may still, because of matters of scale, stimulate and symbolize democratic participation within a nation. (This achievement seems much more difficult in a large country like mine where the actual geographical distances separating people combine with an experience of postmodern fragmentation and disaffiliation to dissipate the gesture to a national fabric symbolized by an isolated audience in a theatre that always appears from some vantage point to be situated at the periphery of the nation.) Although many of the Estonian productions described here had comparatively small audiences, $53 \%$ of its citizens attended the theatre during 2003, which means that the theatre as a cultural institution is still viable as a potential site for a meaningful rethinking of national identity. Epner reports that 12,000 Estonians saw Kalevipoeg in the summer of 2003, not a negligible number for only fifteen performances. The smaller audiences that attended the other performances discussed in these essays may still constitute an important intellectual and artistic group, and probably comprise a significant representation of Estonians positioned in the civil service or governmental sectors. In other words, the theatre tends to address audiences who hold or aspire to leadership roles in the making of a futural national identity. 
The examples of productions discussed in these three essays share more than a deliberate utilization of the rubrics of theatricality. It seems no coincidence that the reworking of national classics, Estonian national myths, and ethnic folk songs and ceremonies takes place concurrently with the representation of new technologies, commodity capitalism, and diasporic collisions. Embodying precisely the predicament of culture in a country reassessing its past and confronting its future, the inability of the binary "global/local" to adequately account for present experience is undeniable. Anneli Saro points to the power of performativity to both confirm and repeat but also to unsettle preceding norms and traditions. In fact, sometimes the same series of signifiers can paradoxically affirm and oppose at the same time, as for example in the Midsummer Night scene in Jalakas's second Werewolf. The contribution of these productions to the process of national identity construction is perhaps contained in their ability to use the ludic processes of the theatrical to interrogate the multiple possibilities and constraints facing the national project of re-imagining Estonian identity.

Raymond Williams provides one fruitful intellectual avenue for understanding what is at stake in these theatrical productions. Convinced of the powerful role of culture in shaping the dominant mode of production in any given society, Williams theorized the categories of residual and emergent cultural practices as a way of accounting for the dynamism of social change. Not merely left-over from the past, residual practices linger because they are necessary to make sense of the present, and "will in many cases have had to be incorporated if the effective dominant culture is to make sense of those areas" (Williams 1980: 41). Emergent features are likewise not only the novel expressions of totally new impulses; they are also always already partially incorporated into the dominant sociality. This model explains how the past and the glimmers of the future can be reworked productively in the present without merely serving as markers of pastness or of futurity. Williams claims that both residual and emergent practices may be either oppositional or merely alternative, may exist alongside each other or challenge each other. Whatever will contribute, over time, to a new social formation will inevitably be made up of just such interpenetrations of past and future. Looking at the Estonian theatre productions described in these essays with Williams' theories in mind, the deconstruction of classical texts, 
myths, and folkloric practices and artifacts can be seen as operations on materials that need to be reworked and partially incorporated into an evolving notion of national identity instead of merely being rejected or destroyed. Indeed, Estonians may need to recall and look again at earlier versions of themselves (as Werewolf, as Setu peasant, as "ironic Estonian") to recognize how far from earlier meanings and values they have moved, but also to interrogate what is worth keeping or refashioning in order to remember the past and create a viable future. Both Epner and Saro point out the way these performances split or displace the traditional narratives and typical national characteristics familiar from the Ur-texts. The character of Tiina in the 1998 version of The Werewolf unravels both earlier interpretations of her figure as either fearful Other to the "blond hair, blue eyes, modesty and slowness of the [...] typical representatives of the Estonian nation" (Saro), or as heroic Dionysian individual who suffers to be free; however it also creates a sense of an alternative, "new, unfamiliar, and cosmopolitan identity of a contemporary Estonian" (Epner). The narrative of Oskar Luts's Springtime may have proved useful to directors Kõiv and Unt because they were able to stimulate the audience's desire for "good old friends" while simultaneously criticizing the basis for these feelings of intimacy. In this case, it is not only the criticism that is important; it is also important to acknowledge the intimate connection with and comfort of the mythical romance of the nation's childhood. A similar complexity of feeling and apprehension is stimulated in Estonian Games. Wedding. First, the Setu ethnic group appears to symbolize both self and other - that is, while in the past Setus have been discriminated against and viewed as outsiders to the Estonian national body, their folk songs turn out to be highly valued for being old and original — and representative of Estonia! Second, the bride was portrayed as a stereotypic Estonian doll-like figure, blond and charming (Saro). This casting ironizes both the stereotype itself (and its gender construct) as well as any possible identification between this figure and the "natural" or "original" Setu people. Thus in the present time of the performance, spectators were looking at the embodied contradictory role of the Setus as abject and prized examples of Estonian identity.

Deconstruction and other poststructuralist methodologies have often been criticized because they depend on a binary structure which reinscribes the original term while purporting to demolish it. At first 
glance, these Estonian examples seem to exhibit this problem. Philip Auslander, paraphrasing Jacques Derrida, describes this deconstructive procedure:

To attempt an exit and a deconstruction without changing terrain, by repeating what is implicit in the founding concepts and the original problematic, by using against the edifice the instruments or stones available in the house [...]. Here one risks ceaselessly confirming, consolidating [...] at an always more certain depth, that which one allegedly deconstructs. (Auslander 1992: 25)

However, I want to argue a different, almost opposite interpretation of this procedure, more in keeping with Raymond Williams than with Derrida. Because the attack on Estonian cultural myths, classical texts, and folkloric practices is built on the assumption of intimate knowledge of them, and personal as well as collective itineraries of memory, experience, and desire, the insights of these performances are predicated on an ongoing utilization of these cultural materials. The inadequacy of the old nevertheless becomes the ground of the insight into something else, something new or different. The ability to analyze, for example, the condition of internal differences within Estonia, whether in terms of Russians or Setus, is partially built on the history of past relationships with both groups and the material changes that have transformed the self/other perceptions of national consciousness. Similarly, the insights into the nature of the theatre apparatus as a memory machine and an organ of re-imagining emerge because a previous knowledge of theatre as a cultural institution is taken for granted and invoked in order to represent the tremors and fault-lines in its current socio-cultural operations.

Furthermore, most of the performances stage an encounter with technology as part of the representation of the new operations of globalization and postmodern living practices. Yet these do not function either as a vision of a preferable cultural paradigm or as an evil threat to indigenous culture. Instead, a complicated interrelationship is figured on the stage. In Estonian Games. Wedding, a series of tensions between the technology of the screen, the theatre, the singers, and the wedding ritual on the one hand, and the naturalness or perhaps better - humanity - of the songs, the actors, the dances, the stage, on the other hand, make for a dis-ease of knowing where to look, what to privilege, what to value. This dilemma actually constitutes the productive "work" of the performance for its viewers and artists. 
Even in an intracultural project such as Estonian Ballads, the clash of Estonian folkloric ballads and Butoh bodily techniques seems to be posited not to maintain the mutual estrangement, but to complicate it by showing traces of each in the other, and furthermore showing bodies trained in one art form but taking on and expressing another in such a way that the traditions seemed compatible and productive. Here the goal seems to be to incorporate something emergent without completely losing its oppositional possibilities and maintaining something residual without the result of validating an unreconstructed return to the past folkloric traditions. The body as a site of competing and simultaneous signifying practices gives this dance theatre its power. Indeed, as Stan Garner has pointed out concerning this phenomena,

embodiedness is subject to modification and transformation, multiple and varying modes of disclosure, and [...] the forms of ambiguity that characterize the phenomenal realm represent experience in flux, oscillating within and between modes of perceptual orientation. (Garner 1994: 51)

Once again we find performance a highly suitable medium for capturing and rendering the ambiguities of experience together with the transformational possibilities of artistic creation. Ester Võsu and Alo Joosepson point out in their essay that "staging" functions analogically as well as theatrically. I would argue the properties of staging contribute to making theatre an ideal form for generating the necessarily dense and fluctuating images of national identity appropriate to Estonia in the present time.

These essays chart a history of theatrical representation in which we can see great change in the portrayal of national identities. If the practice during the Soviet years was to consolidate national opposition through the "manifestation of repressed national feelings" (Epner), the period immediately following independence celebrated the new freedoms by embracing the market economy and dispersing cultural cohesion. However, by the late 1990s and the early years of the new century, something else is clearly evolving - characterized by an inward turning in a global context. In other words, the internal complexity of Estonian identity as indicated from the examples above becomes a preoccupation not unlike the focus on preserving national

4 A further important discussion of a phenomenological model of actors' modes of experience can be found in Zarrilli 2004: 353-666. 
identity during the Soviet period - it seems critical that an examination and reformulation of Estonian identity be pursued. On the other hand, this inward examination must grapple also with the relationship between Estonia and the "New Europe", and between Estonia and a global cultural matrix in which it is clearly embedded. So any inward turning must at the same time be coupled with an outward turn as well - there is a dancing figure here - reaching to comprehend and represent a world of commodified capitalism and homogenized culture in relationship to life on the ground, "at home". Amidst the deconstructive and ironic representations created through the performances described in these essays, one non-ironic figure seems to stand out: in Ain Prosa's parodic production of Kalevipoeg, the character of Kalevipoeg himself seems to have been played without irony, "in a humane manner, freed from both the heroic aura as well as the belittling reputation of a dim-witted barbarian. Kivirähk's Kalevipoeg was a solemn peasant who experienced the tragic loneliness of a leader" (Epner).

In the discussions of reception of the various productions, I can feel my Estonian colleagues' disappointment that some of the audiences were small and that discussion and debate about these richly devised and executed performances did not pursue in depth the socio-cultural implications of these productions. However, perhaps like Kalevipoeg, theatre scholars, artists, and other intellectuals have to face the somewhat lonely task of leading others to explore the issues and experiences raised in these performances. If we cannot overcome commercialism and the more shallow claims of global culture, we can engage in certain residual practices of appreciation and scholarship that may become intertwined with the newly emergent discourses that will mark the future. I am delighted and honored to join them in this project.

\section{References}

Auslander, Philip 1992. Presence and Resistance: Postmodernism and Cultural Politics in Contemporary American Performance. Ann Arbor: University of Michigan Press.

Colleran, Jeanne; Spencer, Jenny S. (eds.), Staging Resistance: Essays on Political Theater. Ann Arbor: University of Michigan Press.

Epner, Luule 2005. Redefining national identity by playing with classics in Estonian theatre at the turn of the century. Sign Systems Studies 33(2): 379-404. 
Kobialka, Michel (ed.) 1999. Of Borders and Thresholds: Theatre History, Practice, and Theory. Minneapolis: University of Minnesota Press.

Kruger, Loren 1992. The National Stage: Theatre and Cultural Legitimation in England, France, and America. Chicago: University of Chicago Press.

Garner, Stanton B. jr. 1994. Bodied Spaces: Phenomenology and Performance in Contemporary Drama. Ithaca: Cornell University Press.

Mäkinen, Helka; Wilmer, Steve E.; Worthen, William B. (eds.) 2001. Theatre, History, and National Identities. Helsinki: Helsinki University Press.

Reinelt, Janelle 1998. Notes for a radical democratic theater: Productive crises and the challenge of indeterminacy. In: Colleran, Jeanne; Spencer, Jenny S. (eds.), Staging Resistance: Essays on Political Theater. Ann Arbor: University of Michigan Press, 283-300.

Saro, Anneli 2005. Von Krahl Theatre revisiting Estonian cultural heritage. Sign Systems Studies 33(2): 405-423.

Taylor, Diana 2003. The Archive and the Repertoire: Performing Cultural Memory in the Americas. Durham: Duke University Press.

Võsu, Ester; Joosepson, Alo 2005. Staging national identities in contemporary Estonian theatre and film. Sign Systems Studies 33(2): 425-472.

Williams, Raymond 1977. Marxism and Literature. Oxford: Oxford University Press.

Zarrilli, Phillip B. 2004. Toward a phenomenological model of the actor's embodied modes of experience. Theatre Journal 56(4): 653-666.

\section{Национальные знаки: эстонский идентитет и театр}

Тот факт, что Эстония занята переосмыслением своего национального идентитета, изучением традиций прошлого и поиском путей в будущее, делает ее замечательным объектом для исследования возможностей театрального искусства в решении вопросов, связанных с национальным идентитетом. Ценность самого театра как институции - категория изменчивая и зависит от разных культурных процессов. Историческая роль эстонского театра в качестве сокровищницы национальных нарративов (особенно литературных) превращает театр в значимое место, где сталкиваются печатное слово и технология, представления “вживую” и архивные записи.

Настоящее эссе является введением к последующим статьям, в которых исследуется то, как Эстонию и ее театральную культуру можно понимать в свете их истории, воспоминаний, современного опыта и будущих возможностей. Идея о том, что “театральное” изначально связано с притворством, уже сама по себе дает прекрасный материал для пересмотра национального идентитета в периоды 
нестабильности и крупных изменений. У постановок, о которых пойдет речь в дальнейшем, точек соприкосновения разумеется больше, чем только сознательное использование театральности. Представляется неслучайным, что переработка классиков национальной литературы, мифов эстонской национальной культуры, народных песен и церемоний происходит одновременно с представлением новых технологий, коллизий потребительского капитализма и диаспорических конфликтов. Театр является важной институцией при переоценке национального, он отражает культурные проблемы в стране, которая переосмысливает свое прошлое и встречается со своим будущим.

\section{Rahvuslikud märgid: eesti identiteet etenduses}

See, et Eesti on hõivatud oma rahvusliku identiteedi ümberdefineerimise ja minevikutraditsioonide ning tulevikupürgimuste uurimisega, teeb temast suurepärase uurimisobjekti, mille näitel vaadelda teatri võimalusi rahvusliku identiteedi üle otsustajana. Teatriinstitutsiooni enda väärtustamise muutumine on osa kultuurilistest tasandumisprotsessidest (kas eestlased hindavad teatrit ja teatris käimist ka tulevikus?). Ka eesti teatri ajalooline roll rahvuslike narratiivide, eriti kirjanduslike, varamuna muudab teatri siinmail tähenduslikuks kohaks kus põrkuvad trükisõna ja tehnoloogia, kehastatud etendused ja arhiivi-esitused.

Käesolev essee on sissejuhatuseks järgnevatele artiklitele, kus uuritakse, kuidas Eestit ja selle teatrikultuuri on võimalik mõista nende kahe ajaloo, mälestuste, tänapäevaste kogemuste ning tulevikuvõimaluste valguses. Idee sellest, et teaterlik/teatripärane on olemuslikult seotud teesklusega, pakub juba iseenesest suurepäraseid võimalusi rahvusliku identiteedi ülevaatamiseks ebastabiilsuse ja suurte muutuste perioodil. Lavastustel, millest järgnevas kolmes artiklis räägitakse, on muidugi suurem ühisosa kui teaterliku/teatripärase teadlik rakendamine. Näib, et see pole juhus, et rahvuslike kirjandusklassikute, eesti rahvuskultuuri müütide ja etniliste rahvalaulude ning tseremooniate ümbertöötamine leiab siin aset samaaegselt uute tehnoloogiate, tarbimiskapitalismi pingete ja diasporaaliste kollisoonide esitamisega. Teater on oluline institutsioon rahvusliku uuesti-tähistamisel, ta kehastab kõige otsesemas mõttes kultuurilist kimbatust maal, mis hindab ümber oma minevikku ja seisab vastamisi oma tulevikuga. 